K. Sattler - D. Elwood - M.T. Hendry · D. Huntley · J. Holmes · P.B. Wilkinson - J. Chambers - S. Donohue - P.I. Meldrum · R. Macciotta - P.T. Bobrowsky

\title{
Quantifying the contribution of matric suction on changes in stability and displacement rate of a translational landslide in glaciolacustrine clay
}

\begin{abstract}
A study of factors impacting landslide displacement rates was conducted on the Ripley Landslide within the Thompson River valley in British Columbia, Canada for the International Programme on Landslides' project \#202. Seasonal and multiyear changes in atmospheric factors cause cyclic fluctuation of matric suction in the vadose zone through changes to the in-situ water content. The ingress of moisture is shown to contribute to multiyear and seasonal loss of stability causing increasing landslide displacement rates, often disregarded in slope stability calculations. However, the water content in the unsaturated zone is important, especially in semi-arid to arid climates where the water table is low and large portions of the slope are unsaturated. Additional tools for studying long-term variations in climate and seasonal changes in water content are presented. These tools are used to characterize historical climate and compare several factors that have resulted in changing landslide displacement rates and magnitude. Infiltration of precipitation and snowmelt directly contributes to matric suction loss in the head scarp and is exacerbated by the presence of tension cracks. While groundwater levels are often correlated to changing displacement rates, changes in matric suction can also influence the rates of displacement. Climatic trends over subsequent years alter the long-term soil water accumulation which impacts rates of landslide displacement. By accounting for additional strength, or potentially a loss in strength due to increasing water content, it is possible to develop a more complete understanding of the mechanisms of climate change which drive displacement rates in the translational, metastable earthen slides that dominate the Thompson River valley. These mechanisms can be applied to comparable river valleys around the world.
\end{abstract}

Keywords Variable matric suction · Infiltration · Soil moisture deficit $\cdot$ Retrogressive landslides

\section{Introduction}

The research presented within this paper is part of the International Programme on Landslides' project \#202 and aims to improve technologies and monitoring methods for the mitigation of natural hazards as part of the Kyoto 2020 commitment for global promotion of understanding and reducing landslide disaster risk (Sassa 2019).
Periodic changes in displacement rates and magnitude for translational, compound landslides, such as the Ripley Landslide in the Thompson River valley, are often hard to anticipate due to the complex interaction of multiple contributing factors. Near the base of these slides, these factors include elevated pore pressures trapped in low hydraulic conductivity layers due to changing hydraulic gradients; loss of landslide toe buttressing due to falling river elevation; and erosion and scour removing material from the slide's toe (Clague and Evans 2003; Eshraghian et al. 2007, 2008; Hendry et al. 2015a). The upper reaches of a slide mass may experience an increasing water content in the vadose zone due to infiltration through tension cracks or the slide mass itself by means of any single factor, or a combination of irrigation; precipitation; snowmelt; or near surface ground thawing, and the release of frozen pore water (Stanton 1898; Bishop 2008; Sattler et al. 2018). The movement of water, both vadose and phreatic, is a universal theme causing landslide instability throughout the valley.

The present study investigates soil moisture deficit (SMD) trends and weather patterns compared to field measurements of matric suction, water content, resistivity, and stable water isotope concentrations over a span of several years to determine their contribution to changes in landslide displacement rates. SMD and longterm weather data are used to identify multi-year and seasonal trends resulting in vadose zone water content changes, similar to studies conducted in the United Kingdom on London Clay (Ridley et al. 2004; Smethurst et al. 2012). Increased water content can lead to deeper infiltration due to increased hydraulic conductivity (Fredlund et al. 1994; Leong and Rahardjo 1997).

As the soil approaches saturation, the matric suction approaches the air entry value (AEV), at which point the matric suction rapidly approaches zero with minor changes in the volumetric water content. The quantification of matric suction based on water content is determined from the soil water characteristic curve (SWCC) (Brooks and Corey 1964; Mualem 1976; van Genuchten 1980; Fredlund and Xing 1994). The matric suction generated by the soil governs the overall shear strength as described by several authors (Bishop 1959; Fredlund et al. 1978; Fredlund and Rahardjo 1993). These variations in water content, and corresponding matric suction, have the potential to reactivate dormant slides and impact long-term displacement magnitudes. 
Background

\section{Significance of the Thompson River valley}

River valleys present several challenges to transportation routes and the agencies operating them across Canada. Cost-efficient transportation routes tend to use river valleys through high relief terrain as their primary corridors due to their relatively consistent relief. However, they are highly susceptible to closures due to geohazards (Hendry et al. 2013). The glacial origins of the surficial soils coupled with the relatively deeply incised topography make retrogressive translational landslides common features in western Canadian river valleys (Pennell 1969; Klassen 1972; Haug et al. 1977; Christiansen and Sauer 1984; Martin et al. 1984; Yoshida and Krahn 1984; Mollard 1986; Eshraghian et al. 2008). The Thompson River valley presents a set of challenges common to several river valleys in western Canada.

The Thompson River is a major tributary to the Fraser River, originating in the mountains to the east of Kamloops, British Columbia (South Thompson) and north towards Valemount, British Columbia (North Thompson). The river is known for its fast-flowing waters combined with its salmon and sturgeon migration. The Thompson River falls under the protected rivers classification in the Fish Protection Act that prohibits dam construction (Fish Protection Act 1997). As a result, river levels are not regulated by manmade structures and the river stages can vary up to $7 \mathrm{~m}$ between the winter low and the spring freshet.

A high concentration of metastable, translational, and retrogressive landslides occurs in the arid climatic region south of Ashcroft, British Columbia affecting the right of way for both Canadian Pacific (CP) and Canadian National (CN) railways (Fig. 1). This corridor is a vital route for all goods travelling between the Port of Vancouver and the rest of Canada. Because of its importance, the rail corridor is one of North America's busiest. Over the last several years, the Thompson River corridor has seen dramatic increases in rail traffic and increases in rail car numbers with some temporary trains reaching up to $2 \mathrm{~km}$ in length (Bunce 2008). Closure of the corridor due to landslide activity would result in millions of dollars of lost revenue for the rail operators and have a direct impact on Canada's economy.

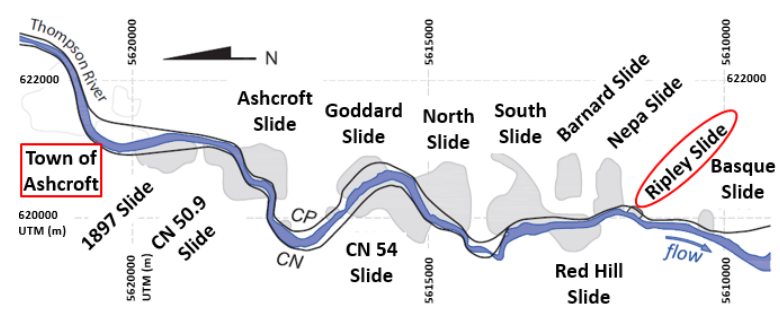

Fig. 1 High landslide concentration south of Ashcroft, British Columbia, Canada (after Eshraghian et al. 2007; Macciotta et al. 2014; Hendry et al. 2015a; Journault et al. 2017)

\section{History and instrumentation at the Ripley Landslide}

Two mainline tracks and one siding on the east side of the Thompson River cross the Ripley Landslide. The steep valley walls on the west side of the Thompson River forces both railway operators to the east side where stability and track disruption have been an issue since the railway's construction in the late 1800 s (Stanton 1898; Bishop 2008).

The Ripley Landslide has been subject to significant instrumentation including, but not limited to, Shape Accel Array (SAA) inclinometers, matric suction sensors (Macciotta et al. 2016), vibrating wire piezometers (Hendry et al. 2018), water content sensors, and electrical resistivity tomography (ERT) (Fig. 2). A weather station was installed and became operational in July 2016. Wildlife cameras installed at each end of the ERT transects to monitor animal activity, confirm weather patterns documented by the weather station and in-ground sensors.

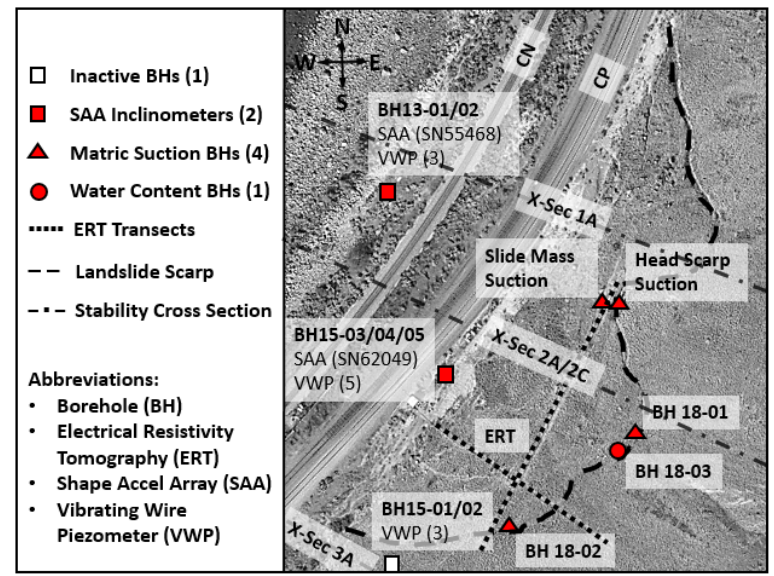

Fig. 2 Plan layout for the Ripley Landslide showing pertinent instrumentation used during the current study

Previous research has focused on the relationship between the rate of displacement and river elevation (Eshraghian et al. 2007, 2008; Hendry et al. 2015a). As the river approaches its seasonal peak in elevation, the landslide displacement rate decreases significantly as the slide mass is partially buttressed by the river and the hydrogeologic regime changes from an upward to a downward gradient. Horizontal displacement velocity compared to river elevation by Hendry et al. (2015a) demonstrated the annual influence of river drawdown on these displacement rates. However, accumulation of moisture on a multiyear time scale is shown by the present study to impact the cumulative multiyear displacement. Seasonal variations in river elevation tend to annually disrupt the long-term cumulative displacement.

\section{Regional and local geology}

The Thompson River valley around the Ripley Landslide has been subjected to at least three glaciations, leading to complex stratigraphic sequences of glaciolacustrine deposits, till, and glaciofluvial outwash (Ryder et al. 1991; Clague and Evans 2003). This valley fill forms terraced bench lands commonly used for agricultural purposes. Away from the river valleys, the groundwater table is 
controlled by the local topography. In the river valleys, the groundwater level is lower due to regional drainage into the river. This flow pattern results in two distinct groundwater regimes with an upper groundwater level perched above the till and a lower, regional groundwater level within the cohesive strata above the bedrock basement.

Post-glacial river incision through weaker stratigraphic sequences has been proposed as the initial triggering factor for landslide displacement (Clague and Evans 2003; Eshraghian et al. 2007, 2008). The failure planes in the Thompson River valley landslides are commonly focused in weak non-swelling clay layers of the glaciolacustrine stratigraphy (Unit 2), as indicated by the red arrows in Fig. 3 (Eshraghian et al. 2007). These failure planes form translational slip surfaces (around 257 masl) where the landslide toe is exposed in the Thompson River, and subjected to large changes in river stage. The variable river stage causes seasonal changes in the direction of hydraulic gradients within the ground. During the winter months when the river level is at its lowest, an upward gradient acts on the base of the rupture surface within a sub-till glaciolacustrine clay layer. During the spring freshet, the higher river stage is greater than the deeper groundwater pressures, and this results in a reversal of the groundwater flow regime and an increase in slope stability. The upward gradient and the corresponding pore water pressures contribute to landslide reactivation or increasing displacement rates (Eshraghian et al. 2007).

The magnitude of displacement varies from year to year. Tension cracks associated with the Ripley Landslide extend upslope over $20 \mathrm{~m}$ above the river elevation (Schafer 2016). The arid climate causes significant evapotranspiration from the surface, maintaining the water table at depths greater than $3 \mathrm{~m}$ based on the investigated borehole locations. Determination of the SWCC from Tempe cell tests on surficial deposits indicate that these sediments can generate variable matric suction due to cyclic changes in water content throughout the year (Sattler et al. 2018). The focus of this paper will be on the upper, perched groundwater table and the influence of infiltration and deeper percolation on the upslope matric suction.

\section{Geotechnical characterization of the Ripley Landslide}

Geotechnical properties for the Ripley Landslide stratigraphy have been investigated and presented in previous studies (Eshraghian et al. 2007, 2008; Hendry et al. 2015a). Subsequent glaciations have caused several unconformities in the stratigraphic sequence. Of the eight units overlying the andesite bedrock proposed by Clague and Evans (2003), some have been completely eroded and are non-existent at the Ripley Landslide. A list of accepted properties for the units that are present is shown in Fig. 3. Tempe cell laboratory tests conducted on the unsaturated upper till (Unit 6) determined appropriate SWCC parameters for the main drying curve (Sattler et al. 2018) and are appended to data from previous studies in Fig. 3.

Slope stability analysis in the present study focused on the unsaturated strength contribution from the diamiction till (Unit 6). All other units were assumed to have no unsaturated strength component as they were composed of coarse-grained material (Unit 8), nonexistent in the cross sections (Unit 3), or present well below the surface where conditions are expected to remain saturated (Unit 2). In the same manner, hydraulic properties were assumed to be saturated for all units other than the till (Unit 6). Unsaturated hydraulic conductivity for the till was estimated in the slope stability analysis by using the field tested saturated hydraulic conductivity and determining the associated hydraulic conductivity function from the SWCC parameters in Fig. 3.

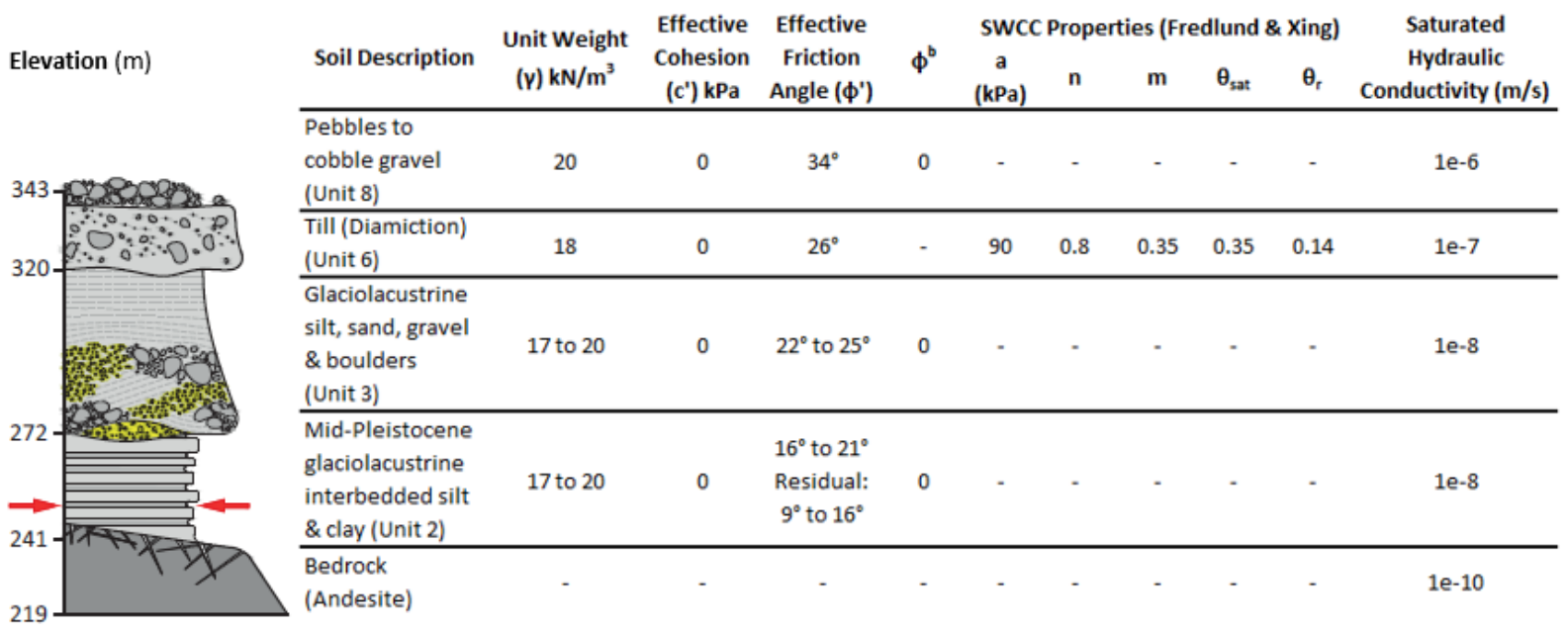

Fig. 3 Dominant stratigraphy for the Ripley Landslide with geotechnical properties used in the current study (after Eshraghian et al. 2008; Hendry et al. 2015a) 
Investigation methods

\section{Proactive infrastructure monitoring and evaluation (PRIME)}

The PRIME system uses an in-place or fixed ERT array, which was developed by the British Geological Survey (BGS). Ongoing surveys of the soil resistivity have been conducted at the Ripley Landslide since the fall of 2017. By conducting periodic measurements of the apparent resistivity between various electrodes in the ERT array, it is possible to identify patterns of changing resistivity related to changes in the subsurface volumetric water content (Gunn et al. 2015). Once the SWCC and its associated hysteresis is known, the volumetric water content can be used to estimate the matric suction for stability calculation considerations.

The ERT network at the Ripley Landslide consists of two perpendicular intersecting rows of ERT electrodes installed in $20 \mathrm{~cm}$ deep trenches as detailed by Huntley et al. (2019a). An initial survey of electrical resistivity detailed coarse-grained (high resistivity) and finegrained (low resistivity) materials in the subsurface directly below the ERT electrodes. Subsequent surveys have analysed changes in the resistivity from the initial background survey. These changes are directly correlated to temporal changes in soil water content and temperature where lithology and porosity are constant (Bobrowsky et al. 2017; Holmes et al. 2018; Sattler et al. 2018; Huntley et al. 2019b).

ERT is a valuable method for determining large-scale stratigraphy and expands upon the knowledge gained during previous studies conducted at the Ripley Landslide (Huntley et al. 2019b; Holmes et al. 2020). As the PRIME system is a permanently installed ERT array, a fourth dimension of observation, time, is used to study the seasonal and long-term changes in resistivity associated with changes in subsurface water content, such as the infiltration of water. The electrode array extends across the slide mass, intersecting the tension cracks at two locations along its length. As precipitation, snowmelt or ground thawing occur, corresponding changes in electrical resistivity are documented and visually represented in a tomograph. The method is particularly advantageous in the tension crack regions where it is possible to observe the depth and extent of surface water penetration. Currently, ERT only provides relative changes and the actual in-situ water contents are not known. As a result, validation and determination of matric suctions are still required.

\section{Stable isotope determination}

The source and degree of evaporation (fractionation) for vadose zone pore water were studied using a method of stable water isotope analysis known as direct vapour equilibration and laser spectrometry (DVE-LS). DVE-LS analysis has been developed in the past decade (Wassenaar et al. 2008) and has been revised by Hendry et al. (2015b). Wassenaar et al. (2008) showed that the DVE-LS method can accurately establish deuterium $\left({ }^{2} \mathrm{H}\right)$ and oxygen-18 $\left({ }^{18} \mathrm{O}\right)$ isotope concentrations from bagged soil samples with volumetric water content above $5 \%$.
Source zones for potential infiltration were identified by comparing soil water isotope concentrations to water isotopes collected from the Thompson River, a nearby creek, and local precipitation. Sealed bag soil samples for stable water isotope analysis were recovered from the upper $2.7 \mathrm{~m}$ of the Ripley Landslide's head scarp region. Laboratory testing confirmed the volumetric water content exceeded requirements for all sample depths analysed (Sattler et al. 2019). Previous stable water isotope determination was conducted by Schafer (2016) on cleaned mud rotary samples at depths greater than $6 \mathrm{~m}$. These samples were collected from the mid slide mass region but provide information on the deeper flow regimes present within the landslide.

Stable water isotope concentrations were compared to the global meteoric water line (GMWL) developed by Craig (1961) and later refined by Rozanski et al. (1993). The local meteoric water line (LMWL) was used to determine the relative evaporative fractionation and local evaporative line (LEL) for infiltrated water. Local meteoric water lines have been published from water sample collection in Edmonton, Alberta and The Pas, Manitoba (Western Interior) (Hage et al. 1975; Clark and Fritz 1997). Higher concentrations of $\delta^{2} \mathrm{H}$ and $\delta^{18} \mathrm{O}$ indicate enrichment and lower concentrations indicate depletion. By plotting the isotopic signature and comparing the relative concentrations to the LMWL, it was possible to determine the surficial climate during infiltration.

\section{Soil moisture deficit (SMD)}

Calculation of soil moisture deficit for a given site uses a combination of climatic conditions. It is common to develop the calculation over a longer period (10 days to 1 month) to avoid short term discrepancies caused by soil heat flux (Allen et al. 1998). Climatic highs and lows over the observation period help identify multiyear patterns of wet and dry cycles. Soil moisture deficit is calculated as the difference between the estimated evapotranspiration and actual precipitation, when runoff is excluded.

$S M D=(E T x d)-P$

where,

$E T$ is average estimated daily evapotranspiration for a particular month [mm day ${ }^{-1}$;

$d$ is the number of days in the month; and

$\mathrm{P}$ is the measured monthly precipitation [mm].

Precipitation rates above $25 \mathrm{~mm} / \mathrm{hr}$ are rare for the study site (Fig. 12). However, the highest runoff would be expected during summer when near-surface soil water content and unsaturated hydraulic conductivity are low. As such, the SMD would be higher due to the runoff component. During spring snowmelt, runoff is expected to be lower because near-surface soil water content and the unsaturated hydraulic conductivity are higher. The water available for evaporation would increase, resulting in a lower SMD. 
The actual evapotranspiration provides the most accurate estimate of soil moisture deficit. However, in lieu of the required instruments, potential evapotranspiration provides a viable tool for a year-toyear comparison of wet/dry cycles (Allen et al. 1998). In this study, evapotranspiration estimates are based on physical measurements of atmospheric variables with site-specific assumptions related to the vegetation cover. In locations where vegetation height remains consistent throughout the year, the aerodynamic resistance factor would remain relatively steady. However, the surface resistance changes due to solar radiation, leaf temperature, vapour pressure deficit, leaf water potential, and carbon dioxide concentration (Jarvis 1976, Stewart 1988). It can be difficult to estimate many of these parameters as they are highly variable based on location. The current study does not account for water stress but does involve site-specific vegetation parameters. By neglecting water stress, the SMD can be lower than the estimated values presented in this study, especially during dry periods. The estimated evapotranspiration is calculated based on the PenmanMonteith (1965) equation.

$Q_{E}=\frac{\Delta\left(Q_{N R}-Q_{G}\right)+\rho c_{p}\left(e_{s a t}(T)-e_{r e f}\right) r_{a-h^{-1}}}{\Delta+\gamma\left(1+r_{S} / r_{a-h}\right)}$

where,

$\Delta$ is the slope of the saturated vapour pressure curve $[\mathrm{Pa} / \mathrm{K}]$;

$\mathrm{Q}_{\mathrm{NR}}$ and $\mathrm{Q}_{\mathrm{G}}$ are net radiation and soil heat flux $\left[\mathrm{W} / \mathrm{m}^{2}\right]$; $\rho$ is the density of air $\left[\mathrm{kg} / \mathrm{m}^{3}\right]$;

$c_{p}$ is the specific heat of the air $[\mathrm{J} / \mathrm{kg} \mathrm{K}]$;

$\mathrm{e}_{\text {sat }}(\mathrm{T})-\mathrm{e}_{\mathrm{ref}}$ is the vapour pressure deficit $[\mathrm{Pa}]$;

$\gamma$ is the psychrometric constant $[\mathrm{Pa} / \mathrm{K}]$; and

$r_{s}$ and $r_{a-h}$ are surface and aerodynamic resistance, respectively $[\mathrm{s} / \mathrm{m}]$.

Weather station data used in the calculation included hourly readings of wind speed (mechanical anemometer), relative humidity, air temperature, and atmospheric pressure within a $60 \mathrm{~km}$ radius of the research site. Relative humidity and air temperature are expected to correlate reasonably well over distances up to $100 \mathrm{~km}$, if topographic and weather changes are not abrupt and the aridity between sites in consistent (Allen 1996). Wind speeds are expected to have the poorest correlation although they should be similar over long periods of record.

In all cases, data used in the calculation was collected within $60 \mathrm{~km}$ of the study site and located in the Thompson River valley. A weather station on site has provided readings of air temperature and precipitation at 15-minute intervals since October 2016. However, an anemometer was not installed until August 2019. As such, Environment Canada (2020) data was used until October 2016 for air temperature data and August 2019 for wind speed data. Beyond those dates, the more representative on-site measurements were used for the evapotranspiration estimate. The soil moisture deficit over the past decade was determined for the Ashcroft area based on the gathered measurements used in conjunction with Eqn. 1 and Eqn.2.

Net available radiation was determined for the slope $\left(13^{\circ}\right)$ and aspect $\left(135^{\circ}\right)$ angle based on approximated clear sky radiation estimates (Hargreaves and Samani 1985). Inclined solar radiation estimates were calculated based on the methods presented by the American Society of Civil Engineers (ASCE 2005) and Allen et al. (2006).

\section{Matric potential (suction) monitoring}

Advances in matric suction instrumentation have progressed over the past few decades in the soil science discipline to meet agriculture irrigation demands (Campbell 1988). Measurement of the in-situ potential has proven rather difficult due to limitations in the methods, and the wide range of values that matric suction can achieve (Guan, 1996; Ridley and Wray 1996; Rahardjo and Leong 2006; Tarantino et al. 2008). However, advancements have resulted in more efficient and reliable monitoring methods due to improved manufacturing, and increased sensitivity in sensors for both in-situ water content and matric water potential (suction). The contribution of matric suction is a factor for stability in slopes with extensive vadose zones and should be considered in many geotechnical applications (Leroueil 1999; Blight 2003; Siemens 2018).

The matric suction sensors used in this study are also known as dielectric matric potential sensors (indirect measurement of water potential) and consist of a printed circuit board placed between two manufactured circular porous stones (each is $31.4 \mathrm{~mm}$ in diameter and $2.8 \mathrm{~mm}$ thick). The sensor body also contains an internal thermistor for temperature measurements. Measurements of the relative permittivity (or dielectric constant) for the porous ceramic stones are directly correlated to water content based on known values of the dimensionless relative permittivity for air, the ceramic stone, and water which are 1, 5, and 80, respectively (Meter Group 2019). The measurement of relative permittivity depends on the amount of water that occupies pore space in the ceramic stone. As a result, the relative permittivity of the stone is directly related to water content through a unique relationship. The manufacturer has determined the SWCC for the ceramic material in the porous stone using mercury porosimetry. The sensors are more accurate during a soil's drying phase because the calibrated SWCC was performed on the drying portion of the hysteresis loop, due to natural drying phases typically far exceeding natural wetting phases. The manufacturer states that hysteresis errors are less than $10 \mathrm{kPa}$ between -20 and $100 \mathrm{kPa}$ (Meter Group 2019). The SWCC relationship allows for direct computation of water potential, or suction, based on the water content of the porous stone. The sensors output readings between -9 and $-100,000$ $\mathrm{kPa}$. Accurate measurement of water potential $( \pm 10 \%$ accuracy from -9 to $-100 \mathrm{kPa}$ ) occurs closer to the wet end of the measurement spectrum (Meter Group 2019). For water potential drier than $-100 \mathrm{kPa}$, the sensor calculation uses a linear relationship between the 
logarithm of water content and the logarithm of water potential which has demonstrated accuracy down to $2000 \mathrm{kPa}$ (Meter Group 2019). The porous stone requires intimate contact with the surrounding soil over the entire ceramic surface to maintain water potential equilibrium (Meter Group 2019). Therefore, field personnel must hand-pack the soil onto the sensor. After ensuring complete coverage, the sensor is installed in a shallow borehole and backfilled with compacted cuttings.

Matric suction sensors were installed at several locations across the Ripley Landslide head scarp. The depth of the sensors was limited by the use of a hand auger to install and the prevalence of cobbles within the upper soils within the slope. Sensors were installed at a minimum depth of $0.3 \mathrm{~m}$ and a maximum depth of $2.7 \mathrm{~m}$ below the ground surface (Sattler et al. 2018). Vertical sensor intervals were consistent between boreholes and positioned with $0.3 \mathrm{~m}$ spacing in order to achieve enough vertical stratigraphic resolution in the water content and matric suction datasets. A single borehole was drilled into the slide mass approximately $4.5 \mathrm{~m}$ from a head scarp borehole. The boreholes were hypothesised to be able to confirm the expected differences in infiltration between the head scarp and the slide mass due to the influence of tension cracks, as well as demonstrate how the matric suction varies within the active zone both spatially and temporally.

\section{Slope stability involving suction}

To determine the potential impact for a loss in matric suction on landslide stability, transient seepage analysis was used to simulate pore water pressures. Hydraulic properties of the vadose zone, presented in Fig. 3, were used in the seepage analysis. Limit equilibrium slope stability analysis was conducted for three cross sections (shown in Fig. 2) along the Ripley Landslide using the generated pore pressures. The cross sections were selected in the same locations with the same material parameters as those developed by Hendry et al. (2015a) and Schafer (2016) combined with geologic profiles based on geophysical survey results (Huntley et al. 2019a). The analysis was conducted using SLOPE/W and SEEP/W from GeoStudio 2019 R2 version 10.1 (Geoslope International Ltd 2019). Cross section $1 \mathrm{~A}$ was the most northern stability cross section while cross section 2 cut through the middle of the Ripley Landslide, with approximately equal proportions of slide mass north and south of the cross section (Fig. 2). Cross section $2 \mathrm{C}$ represented a $2.3 \mathrm{~m}$ pore water pressure increase in $\mathrm{BH}_{15}-\mathrm{O} 3$ (compared to no increase in cross section $2 \mathrm{~A}$ ) that was observed in February 2017 during an occurrence of increased landslide displacement rate. Cross section $3 \mathrm{~A}$ was the furthest south and represents an area at the southern extents of the Ripley Landslide (Fig. 2).

Back-analysed factor of safety (FOS) was determined at each cross section based on the landslide displacement event in February 2017. At the time, river elevation was near the seasonal minimum (263 masl). To compute the effect of river elevation, the seasonal maximum river elevation (270 masl) was input to determine the stability impact due to river elevation. The pore water pressures from the back-analysed FOS analysis for February 2017 was then used as a starting point for transient seepage estimation of infiltration and subsurface pore pressure changes from two real-life scenarios of snowmelt and precipitation.

The snowmelt scenario involved a $0.3 \mathrm{~m}$ snowpack (typical for the Ripley Landslide) combined with a rise in air temperature from January 3, 2020 to January 15, 2020. Preceding air temperatures hovered at or below zero degrees Celsius prior to the sharp increase in air temperature that would trigger snowmelt. Air temperature, precipitation, and relative humidity from the on-site weather station were combined with the estimated evaporation to form the land-climate interaction boundary set at the landslide surface. The transient analysis calculated the pore water pressures at 0.25-day increments and stability was analysed at each step to record the change in FOS for the fully specified translational slip surface with a base at 257 masl.

The precipitation scenario did not coincide with snowmelt in early 2020 so the two scenarios were not analysed together. Instead, a $25 \mathrm{~mm}$ precipitation event occurred over a 15-day period from January 31, 2020 to February 14, 2020. Starting at back-analysed pore pressures and stability characteristics, a land-climate interaction boundary layer was applied to the surface of each cross section with the measured air temperature, precipitation, and relative humidity for the new period of study. Inputs for the estimated evaporation were used by the seepage analysis software to determine the outward flux to be subtracted from the infiltration. As with the snowmelt scenario, 0.25 -day increments of pore pressure were calculated, and the FOS was determined at each increment. The same fully specified slip surface was used for this analysis.

The slope stability analysis employed the extended Mohr-Coulomb criterion based on the effective stress equation for unsaturated soil (Fredlund et al. 1978).

$\tau=c^{\prime}+\left(\sigma_{f}-u_{a}\right)_{f} \tan \phi^{\prime}+\left(u_{a}-u_{w}\right)_{f} \tan \phi^{b}$

where,

$c^{\prime}$ is the effective cohesion;

$\left(\sigma_{\mathrm{f}}-\mathrm{u}_{\mathrm{a}}\right)_{\mathrm{f}}$ is the net normal stress at failure;

$\phi '$ is the material friction angle;

$\left(\mathrm{u}_{\mathrm{a}}-\mathrm{u}_{\mathrm{w}}\right)_{\mathrm{f}}$ is the matric suction at failure; and

$\phi^{\mathrm{b}}$ is the angle describing the rate of change in suction with increase in shear strength.

The translational shear zone at 257 masl was assumed to have residual strength properties derived from the back analysed FOS (shown in Fig. 3) during periods of increased displacement rates. The fully specified slip surface through the translational shear zone was based on instrumentation records from previous studies at the Ripley Landslide (Hendry et al. 2015a, Schafer 2016). 
Results and discussion

New approaches to the use of ERT, stable water isotope analysis, long-term weather data, and matric suction sensors were studied to determine the impact of variable matric suction on stability at the Ripley Landslide. Water source for infiltration and seasonal evaporation characteristics were determined through detailed stable water isotope analysis. Longer term weather patterns were used to indicate years that may be drier or wetter than average, which affects the soil's unsaturated hydraulic properties through the infiltration of water. The quantitative impact on soil suction was derived from measured meteorological trends, considering the impact

a)

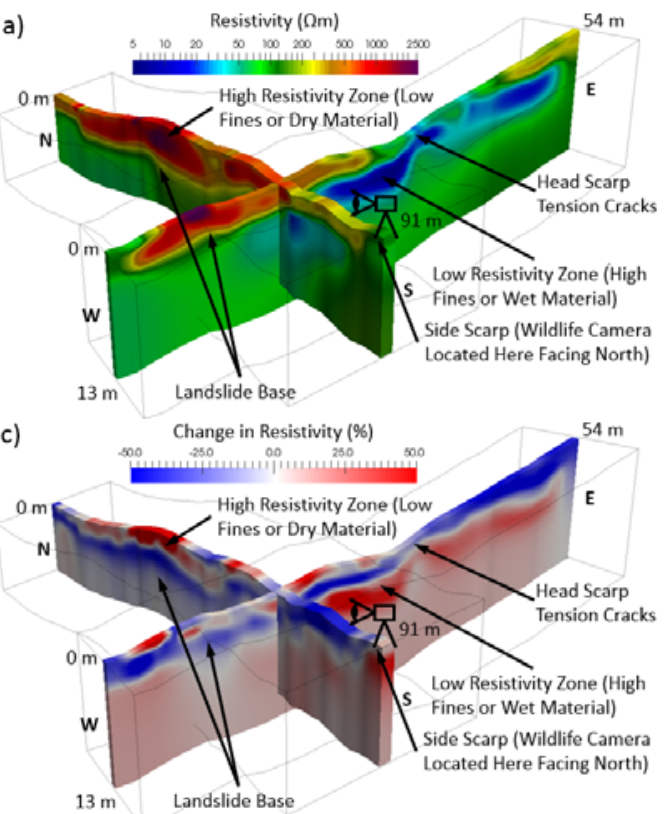

e)

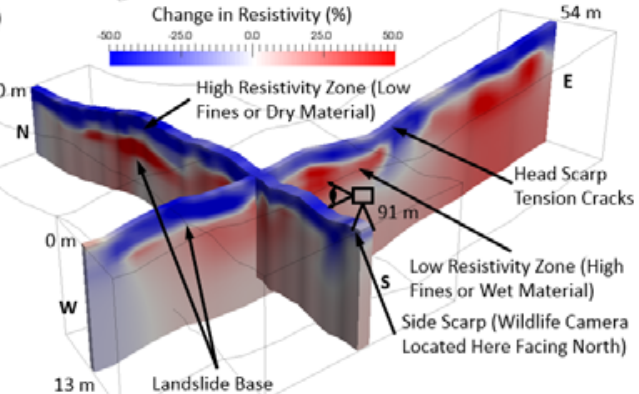

of rapid snowmelt and high intensity precipitation events. When these events coincide with low river elevation and wet surface conditions, the combined effect is shown to have a measurable impact on the slope stability for a fully specified slip surface.

\section{Net infiltration observations}

The PRIME system using ERT has been operational since December 2017 providing weekly visual representation of changes in soil resistivity (water content). The initial resistivity survey was conducted in December 2017 and provides a base to which all future measurements are compared (Fig. 4a-4b). The subsurface and surface
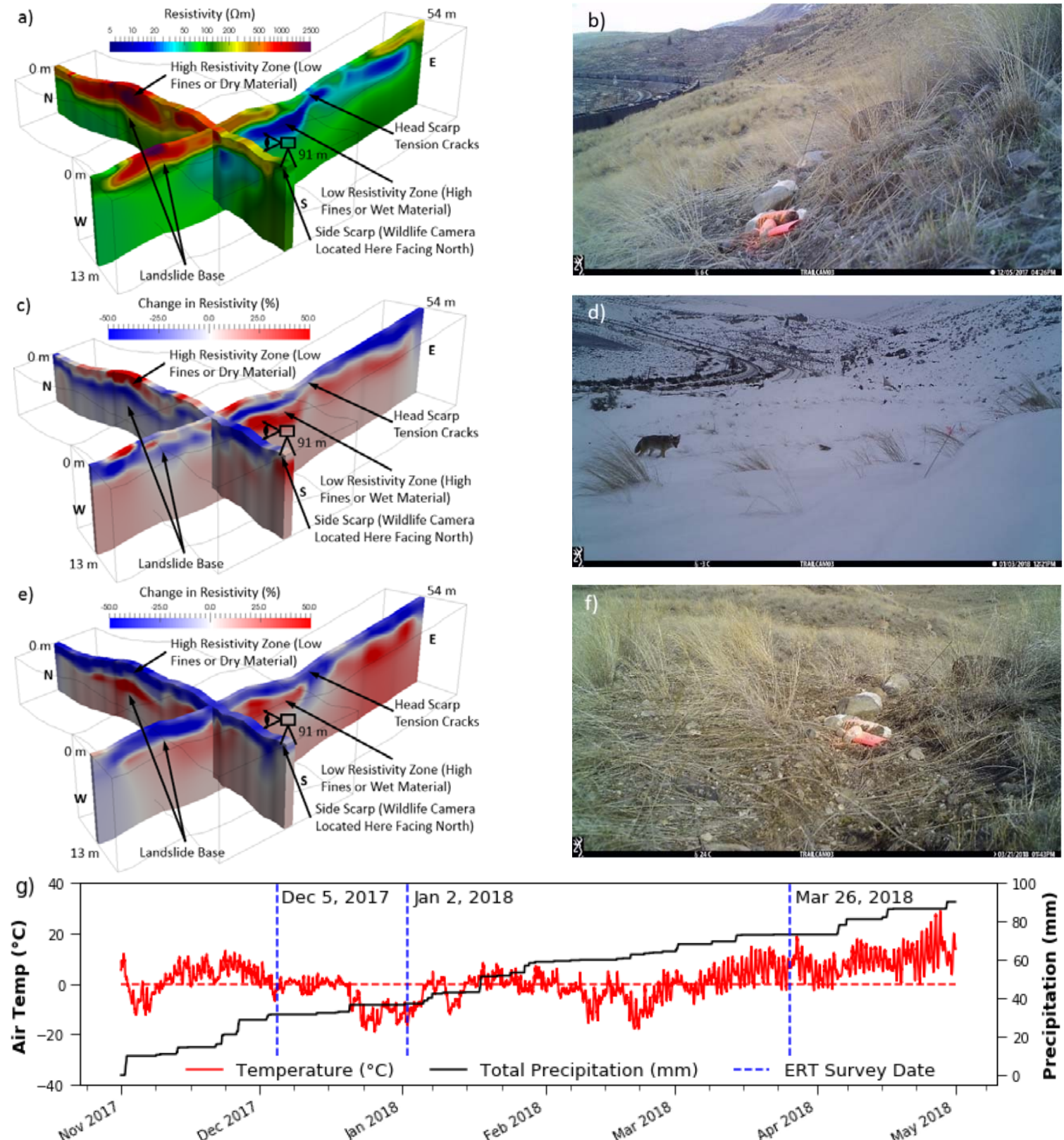

Fig. 4 Changes in resistivity due to infiltration across Ripley Landslide ERT transects: a Background resistivity survey on Dec. 5, 2017 showing dual axis cross-section b Surface conditions on Dec. 5, 2017 c Resistivity change from Dec. 5, 2017 to Jan. 2, 2018 d Field image from Jan. 3, 2018 e Resistivity change from Dec. 5, 2017 to Mar. 26, 2018 f Field image from Mar. 21, $2018 \mathrm{~g}$ Temperature and total precipitation since Nov. 1, 2017 (after Holmes et al. 2020; Sattler et al. 2018; Huntley et al. 2019b; Huntley et al. 2020) 
features are described in the figure indicating the slide mass extent and potential infiltration zones including the slide tension cracks. Subsequent surveys during the spring of 2018 depict changes in resistivity due to changes in soil water content caused by snowmelt and ground thawing (Fig. 4c-4f). In Fig. 4c and Fig. 4e, positive changes in resistivity (associated with decreasing water content) are indicated in red while negative changes in resistivity (associated with increasing water content) are shown in blue. Timestamps are provided with each tomograph to provide reference to the temporal record of temperature and total precipitation (Fig. $4 \mathrm{~g}$ ). Total precipitation is a function of positive temperature. Frozen precipitation accumulated on the collection basin is released when temperatures rise above freezing. As a result, there are spikes in total precipitation due to melting of the accumulated snowfall (Fig. 4g).

The progression of snowmelt and ground thawing is evident in the tomography, particularly in the head scarp tension crack locations. The near surface soil starts to indicate lower resistivity (blue shading progressing from Fig. $4 \mathrm{c}$ to Fig. 4e) as the snow melts and ground thaws causing increasing water content. In the head scarp tension cracks, water starts to infiltrate deeper and is visually represented in the tomograph by a blue crescent shading extending through the high resistivity red shading at greater depth (Fig. 4). The wildlife cameras help document snowmelt progression (Fig. $4 \mathrm{~d}$ to Fig. 4f) corresponding to changing resistivity in the ERT surveys (Fig. 4c to Fig. 4e).

Accumulation of precipitation has the potential to contribute to deeper infiltration. Surface runoff trapped in the head scarp tension cracks leading to deeper infiltration is clearly indicated by the ERT survey from Mar. 26, 2018 (Fig. 4e). Water trapped in snowmelt is released when temperatures start to rise above freezing (Fig. 4g). If the snowpack is melting and the ground is thawing, the soil is subject to increasing hydraulic conductivity due to an increasing water content. The increasing water content starts at the ground surface and progressively makes its way downward through the vadose zone as infiltration and percolation occurs. The saturated hydraulic conductivity represents the maximum possible hydraulic conductivity and is achieved approximately when the water content is equal to the AEV. Persistent precipitation events in early spring that occur concurrently with low river elevation further increase pore water and reduce the suction that can be generated by the soil. If minimum SMD and minimum river elevation are achieved in multiyear trends, infiltration during early spring can significantly contribute to changes in the landslide displacement rate.

\section{Isotopic analysis of infiltration}

Stable isotope analysis from recovered soil samples was used to identify infiltration source waters spatially and temporally (seasonal infiltration). By comparing stable water isotope testing results to the GMWL and LMWL, it is possible to determine the LEL (Fig. 5). The relative position of samples on the plot implies certain information about the groundwater movement.

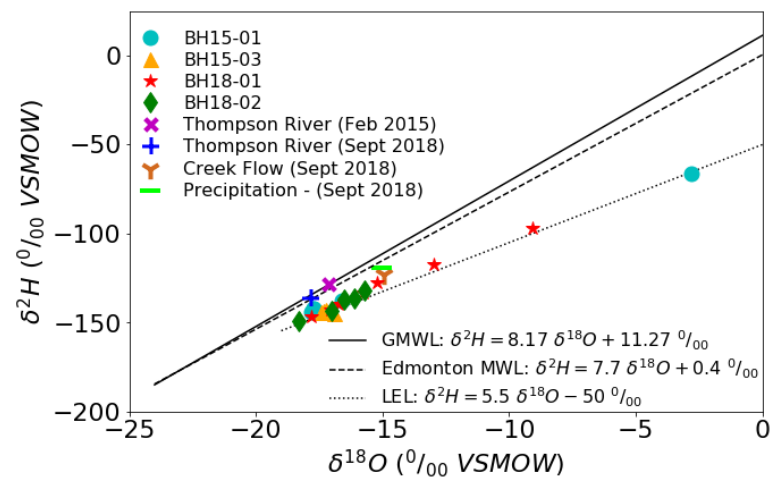

Fig. 5 Stable water isotope signature for soil samples, the Thompson River, and local precipitation (after Schafer 2016)

Based on stable water isotope samples collected in September 2018, the slope of the LEL was determined to be around 5.5. This slope indicates that the shallow samples were highly enriched by evaporation fractionation. Temperatures were relatively high $\left(20^{\circ} \mathrm{C}\right)$ during the sampling period and evaporation has the potential to further enrich water prior to infiltration. In the summer, plant activity utilizes much of the shallow groundwater. The deeper the sample collection, the more isotopically depleted the samples. Isotopic depletion is characteristic of cooler climates (Clark and Fritz 1997). The samples remain slightly below the GMWL and LMWL (Fig. 5), indicating that minimal evaporation has occurred prior to surface ingress. Therefore, soil water content in the upper $2.7 \mathrm{~m}$ is derived from cold temperature surface infiltration, most likely during spring thaw.

The stable water isotopes become more depleted with depth as indicated by $\mathrm{BH} 18$-o1 from the 2018 study (Fig. 6). This is characteristic of infiltration near the surface during warm weather. On the other hand, $\mathrm{BH}_{1} 8$ 02 demonstrates a decrease in $\delta^{2} \mathrm{H}$ and $\delta^{18} \mathrm{O}$ followed by slightly increasing concentration with depth forming a dual active zone of changing water content (Fig. 6).

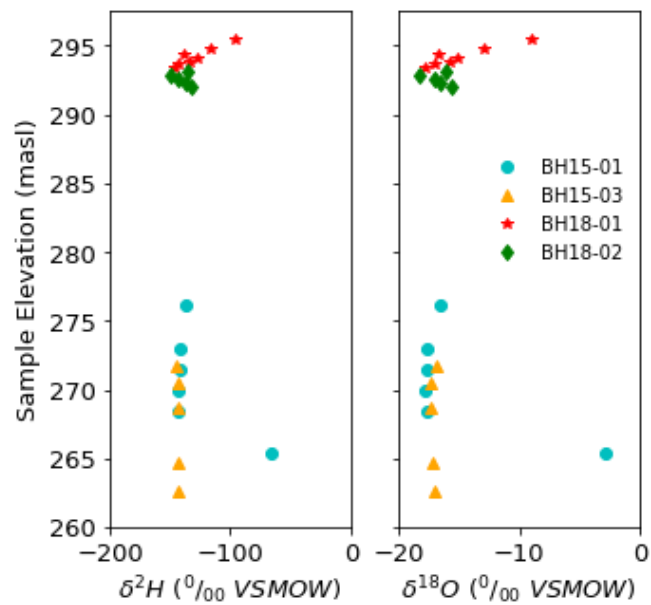

Fig. 6 Stable water isotope profiles from 2015 and 2018 soil samples plotted with depth (after Schafer 2016) 
The topography and aspect angles are distinctly different between $\mathrm{BH}_{1} 8$-O1 (Fig. 7) and $\mathrm{BH}_{1} 8$-02 (Fig. 8) which plays a role in the dual active zone observed in the isotopic profiles. $\mathrm{BH} 18-01$ is exposed to direct sunlight and evaporation whereas $\mathrm{BH} 18-\mathrm{O} 2$ is located partway up a northwest facing slope. As a result, the sunlight exposure of $\mathrm{BH} 18-02$ varies considerably throughout the year. In its protected location infiltration at $\mathrm{BH} 18-02$ may experience less evaporation leading to year-round infiltration. Furthermore, there are considerable differences in the vegetative cover between the two locations which would also have an impact on the annual evapotranspiration.

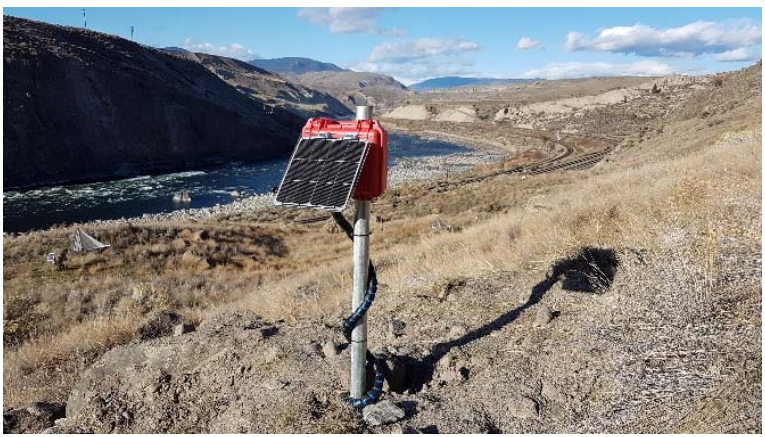

Fig. 7 Facing north at the location of $\mathrm{BH} 18-\mathrm{O} 1$ showing minimal surface vegetation

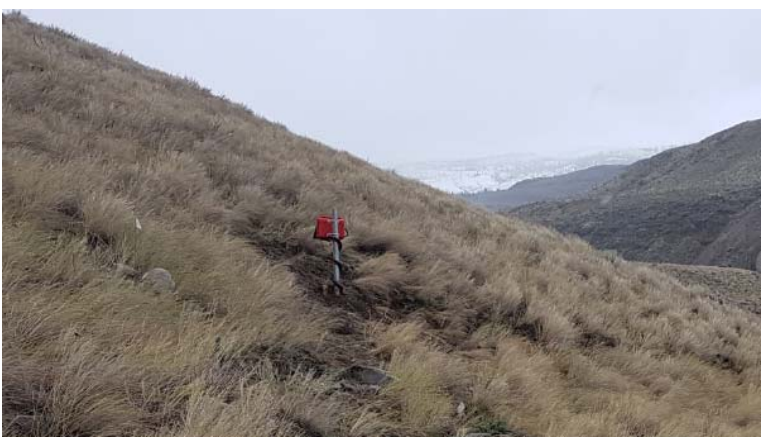

Fig. 8 Facing south viewing $\mathrm{BH} 18-02$ datalogger installation at the base of a steep slope, limiting solar radiation

\section{Meteorological impact on landslide displacement trends}

The ERT surveys and isotope analysis confirm soil water content is derived from surface infiltration. The soil moisture deficit was used to quantify cycles of changing moisture from meteorological data (Hutchinson 1995). A plot of the soil moisture deficit over several years demonstrates which years were wet or dry in comparison to other years (Fig. 9). The large-scale trends in Fig. 9 also demonstrate that there is an annual cycle of soil moisture deficit, similar to seasonal fluctuations in the Thompson river elevation. However, there are some differences between the river elevation and soil moisture deficit trends which can be attributed to snowpack level from the upstream watershed compared to local snowpack levels. For example, data from the summer of 2016 showed the soil moisture deficit dropped by more than $50 \mathrm{~mm}$ from its 2015 peak, suggesting that 2016 was a wetter year. On the other hand, 2017 demonstrated a similar soil moisture deficit to 2015 while the river elevation peaked around $2 \mathrm{~m}$ higher than previous years. If the soil moisture deficit drops below zero, the soil demonstrates a surplus of water. The arid climate of the Ripley Landslide produces soil moisture surpluses infrequently and these periods are typically confined to the winter months as shown in Fig. 9.

Displacement data was compared to soil moisture deficit trends to indicate potential correlations to landslide displacement involving atmospheric interactions. Based on data collected over the past five years, it follows that relatively large displacements occurred after a wet year (2016), while displacement rates were relatively steady following the drier years. A significant displacement of the Ripley Landslide was measured in February 2017 and is evident in the cumulative displacement data plotted in Fig. 9. Displacement rates accelerated again following the drop in Thompson River elevation in summer 2017 due to unbalanced forces remaining in the landslide following the increased displacement in February 2017. The rise in river elevation due to snowmelt in the mountains effectively slowed the displacement rate intermittently for a few months in 2017 .

Prior to the significant displacement in February 2017, the river elevation peaked around 268.5 and 268.3 masl in summer 2015 and summer 2016, respectively (Fig. 9). The minimum river elevation dropped to 263.4 masl in both winter 2016 and winter 2017 (Fig. 9). Therefore, the seasonal peak and minimum river elevation would suggest seasonal gradients to be slightly higher in 2015/16 as opposed to those in 2016/17. However, the

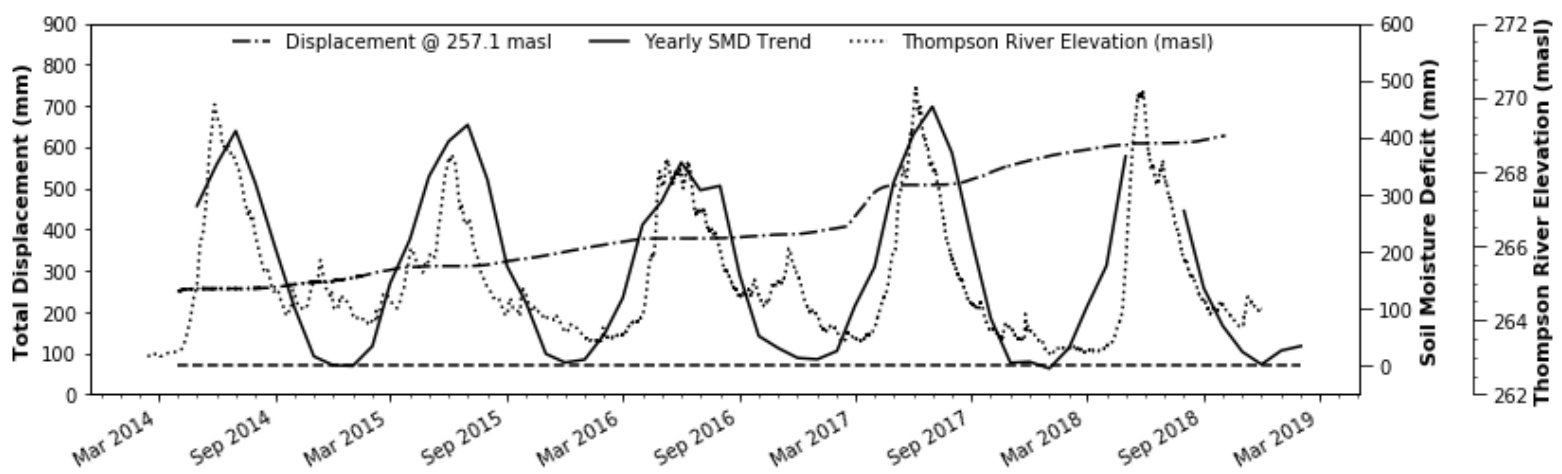

Fig. 9 Lateral SAA displacement in BH13-02 at the 257.1 masl slip surface combined with SMD and river level over the same period 
increased displacement rate occurred in winter 2017, due to a smaller difference in summer peak and winter minimum river elevation. Following the event, the minimum river elevation dropped to 263.1 masl in winter 2018 (Fig. 9). Rates of displacement did not increase in winter 2018 to the same degree they did in winter 2017, even though the river elevation dropped to a lower level in winter 2018 and the river elevation peaked significantly $(2 \mathrm{~m})$ higher in summer 2017 (Fig. 9). The cumulative displacement over several years would appear to be less influenced by the seasonal fluctuation in river elevation and changing hydraulic gradients than the accumulation of soil moisture, as evidenced by the multiyear trends in soil moisture deficit.

\section{Soil suction loss}

Matric suction sensors installed in the head scarp quantified the impact on soil suction which impacts landslide displacement rates. Matric suction has been monitored at the Ripley Landslide since November 2017. Sensors installed in the head scarp and slide mass have continuous records showing ongoing changes in matric suction up to $2.7 \mathrm{~m}$ below ground (BG). Comparing the matric suction to the monthly soil moisture deficit demonstrates an inter-connected relationship between the variables (Fig. 10). As expected, the matric suction in the head scarp and the slide mass drops when the soil moisture deficit is lower (pore-water pressures are less negative). There is a slight delay between a decrease in soil moisture deficit and falling matric suction in the intact slide mass as shown in Fig. 10. The delay is related to the infiltration rate, hydraulic conductivity, and depth of soil above individual sensors.

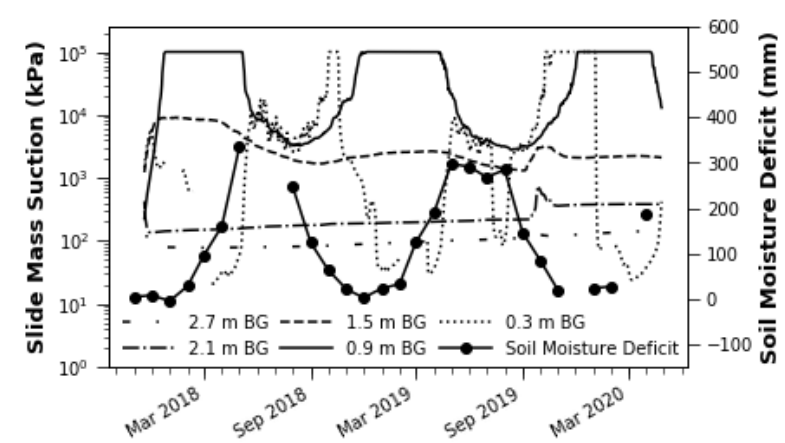

Fig. 10 Slide mass matric suction related to soil moisture deficit

Based on the plotted soil moisture deficit (Fig. 10), 2018 had a drier summer than 2019. The slide mass matric suction indicates higher matric suction in 2018 down to $1.5 \mathrm{~m}$ below surface: showing increasing response time delay vs. depth due to infiltration time and low soil permeability (Fig. 10). The soil suction sensor at $0.9 \mathrm{~m}$ depth in Fig.10 shows that the corresponding peaks in suction are delayed several months when compared with the sensor at $0.3 \mathrm{~m}$. The delay is less pronounced in the head scarp sensors (Fig. 11). The minimal delay in the head scarp sensors is due to more direct and connected flow paths opened by the tension cracks at the head scarp.

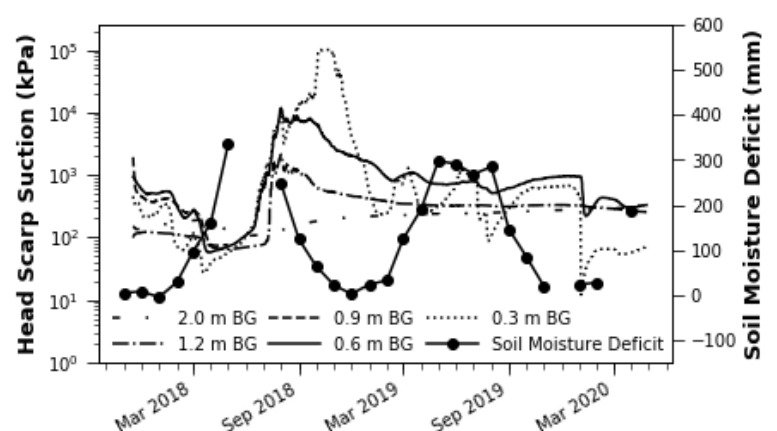

Fig. 11 Head scarp matric suction related to soil moisture deficit

Precipitation and temperature have been measured over a two-year span to document their impact on the soil's matric suction (Fig. 12 and Fig. 13). Matric suction measurements during precipitation events show a loss of suction, especially in the shallow sensors (Fig. 12). Antecedent precipitation affects the subsurface matric suction due to the creation of a variable unsaturated hydraulic conductivity profile. Precipitation following dry periods of low antecedent precipitation has less influence on the suction compared to precipitation following wet periods of high antecedent precipitation. For example, high intensity precipitation during summer 2018 and summer 2019 (Fig. 12) have little impact on subsurface matric suction because high rates of evapotranspiration cause drier soil conditions. As a result, the soil has a lower unsaturated hydraulic conductivity, and less infiltration can occur during the summer months. In early spring, snowmelt of accumulated antecedent precipitation occurs when temperatures are lower and evapotranspiration is less. The influx of melt water causes a loss in matric suction, increasing the soil's unsaturated hydraulic conductivity. This leads to higher infiltration rates during snowmelt for any additional precipitation events that occur while the wet near-surface soil conditions persist (Fig. 12).

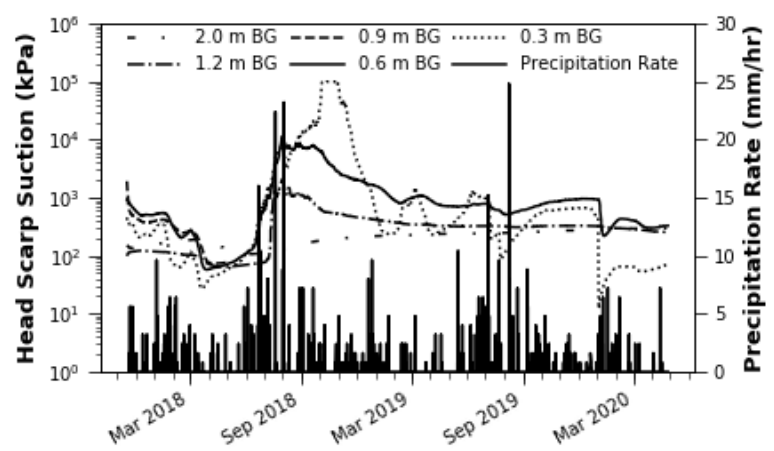

Fig. 12 Temporal record of precipitation rate and associated changes in head scarp matric suction

The Ripley Landslide belongs to a climatic region where the soil freezes, winter snowpack develops, and water accumulates over long periods (5-6 months) before it is released in relatively short periods (days to weeks) as the temperature rises above freezing. While saturation is indicated by matric suction approaching a value of $0 \mathrm{kPa}$, frozen water registers infinite matric 
suction as the surrounding liquid turns into a solid. During this time, suction increases in the freezing zone as the amount of liquid water reduces, generating higher levels of suction (Fig. 13). A suction gradient develops, drawing more water into the freezing zone (Fredlund et al. 2012). When the ground is frozen and snowpack exists at the Ripley Landslide, water is unable to infiltrate from the surface and evaporation ceases.

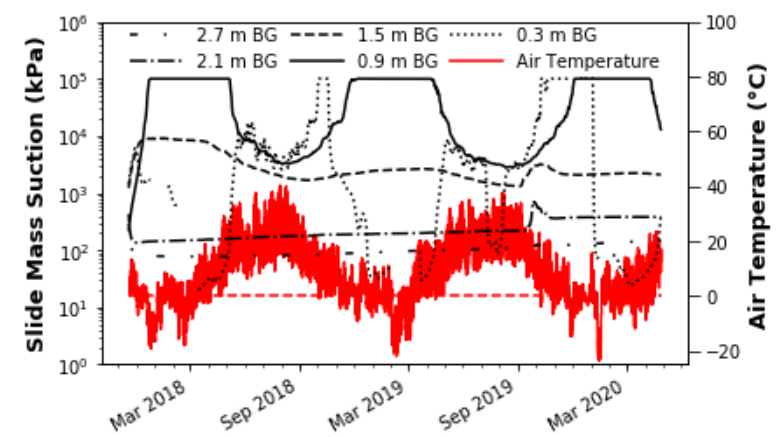

Fig. 13 Temporal record of temperature related to slide mass matric suction

The ground thaws and snowpack melts in the spring causing a large reserve of water to be released in less than a month (Fig. 13). The influx of water available for groundwater recharge reverses the near-surface hydraulic gradient and increases the soil's hydraulic conductivity at a time when air temperatures are lower (less evaporation) and vegetation is inactive, resulting in deeper infiltration. For example, suction at $0.3 \mathrm{~m} \mathrm{BG}$ was much higher than suction at $2.7 \mathrm{~m} \mathrm{BG}$ during summer due to high rates of evaporation in this arid climate (Fig. 13). It is only during the first few months (typically early to mid-March) each year that suction at $0.3 \mathrm{~m} \mathrm{BG}$ falls below the suction recorded at $2.7 \mathrm{~m} \mathrm{BG}$, thus reversing the hydraulic gradient (Fig. 13). The minimum hydraulic gradient between $0.3 \mathrm{~m} \mathrm{BG}$ and 2.7 m BG in 2018, 2019, and 2020 was reached on March 16, March 23, and March 6 , respectively. In chronological order, the yearly minimum hydraulic gradient was calculated as -2.4, -2.9, and -4.9 for $2018-2020$. The net negative hydraulic gradient across the upper $2.7 \mathrm{~m}$ allows for infiltration into tension cracks at the Ripley Landslide. After the period of snowmelt passed, the soil rapidly dried out and positive hydraulic gradients returned, limiting deeper infiltration.

Local snow melt can occur rapidly around the Ripley Landslide and it will take time for the watershed to funnel the resulting runoff into the Thompson River. Furthermore, the mountain snowpack melts slowly and is delayed compared to lower elevation snowpack melting due to temperature differences. As a result, the Thompson River elevation does not increase at the same time as the snow is melting within the river valley. The response is delayed, creating a precarious situation where the matric suction in the landslide is dropping while the buttressing effect from the Thompson River is at a minimum. The river elevation reaches a minimum around the same time as the SMD reaches a minimum
(Fig. 9). The seasonal minimum for shallow matric suction also occurs around the same time, depending on the current weather trends (Fig. 10 and Fig. 11).

The temporal record in Fig. 13 demonstrates that matric suction reaches a minimum later in the summer. During the summer, infiltration is reduced as air temperatures are elevated (more evapotranspiration) and vegetation takes up more of the precipitation. Between late May or early June, the Thompson River typically achieves its maximum elevation (Fig. 9) and the potential for landslide displacement has decreased. After reaching a minimum matric suction, the matric suction increases during autumn (Fig. 13) as precipitation totals decrease (Fig. 12) and vegetation reduces activity, allowing for deeper infiltration. In late fall, the freezing front progresses from the ground surface through the active zone. Any shallow frozen sensors register infinite suction in the soil due to the subsequent liquid-solid phase transition and loss of pressure equilibrium between the ceramic stone and the soil pore water. Suction data was removed when sensor temperatures were less than $0^{\circ} \mathrm{C}$ (gap around Feb. 2018 in Fig. 13).

Seasonal changes in river elevation combined with variable suction and the impact on slope stability

In this study, analysis focused on a specific set of conditions during which fluctuations in the upper till (Unit 6) matric suction are critical to slope stability. For example, displacement tends to occur when the river level approaches its minimum elevation (263 masl was used for this analysis). At low river elevation, pore water pressures in boreholes $\mathrm{BH}_{13}-\mathrm{Ol}_{\text {and }} \mathrm{BH}_{15}-\mathrm{O} 3$ are also expected to be relatively low. SAA displacement data during February 2017 indicated movement at 257.1 masl under these conditions. A back analysed FOS (including the unsaturated zone) was calculated for cross sections $1 \mathrm{~A}, 2 \mathrm{~A}, 2 \mathrm{C}$, and $3 \mathrm{~A}$ during that period as $0.96,1.24,1.13$, and 1.03, respectively (back-analysed FOS for cross section $2 \mathrm{C}$ shown in Fig. 14c). All slip surfaces were analysed as fully specified slip surfaces with a horizontal shear plane (residual strength characteristics) located at 257.1 masl. These back-analysed FOS were used as starting points for the analysis shown in Fig. 15b-15c. When the unsaturated zone was ignored, the back analysed FOS for cross sections $1 \mathrm{~A}, 2 \mathrm{~A}, 2 \mathrm{C}$, and $3 \mathrm{~A}$ was reduced to $0.93,1.16,1.09$, and 1.00 , respectively. Using the maximum river elevation (around 270 masl), a FOS for cross sections $1 \mathrm{~A}, 2 \mathrm{~A}, 2 \mathrm{C}$, and $3 \mathrm{~A}$ was estimated to be 1.06, 1.43, 1.27, and 1.10, respectively. Therefore, seasonal river fluctuation (up to $7 \mathrm{~m}$ ) accounts for up to $19 \%$ change in FOS due to the river buttressing effect.

A three-month snapshot of the important parameters is shown in Fig. 15a to demonstrate the impact of warming temperatures driving snowmelt and precipitation events on matric suction from December 2019 to March 2020. A spike in air temperatures on January 3, 2020 drives the release of frozen surface water and infiltration which lowers matric suction (Fig. 15a) and the overall FOS (Fig. 15b) over a 12-day period. Intermediate rises in FOS are related to the shifting of 

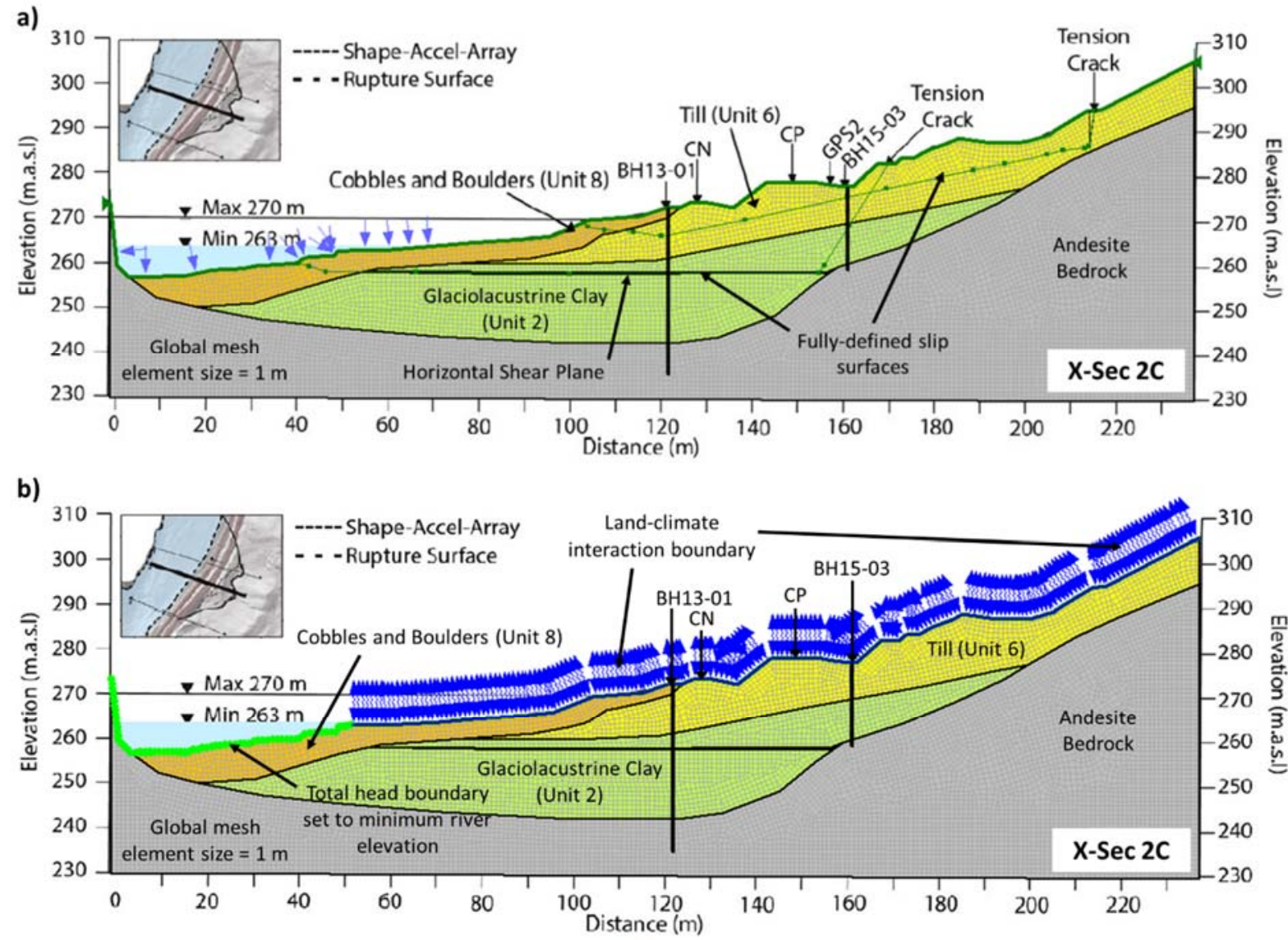

c)
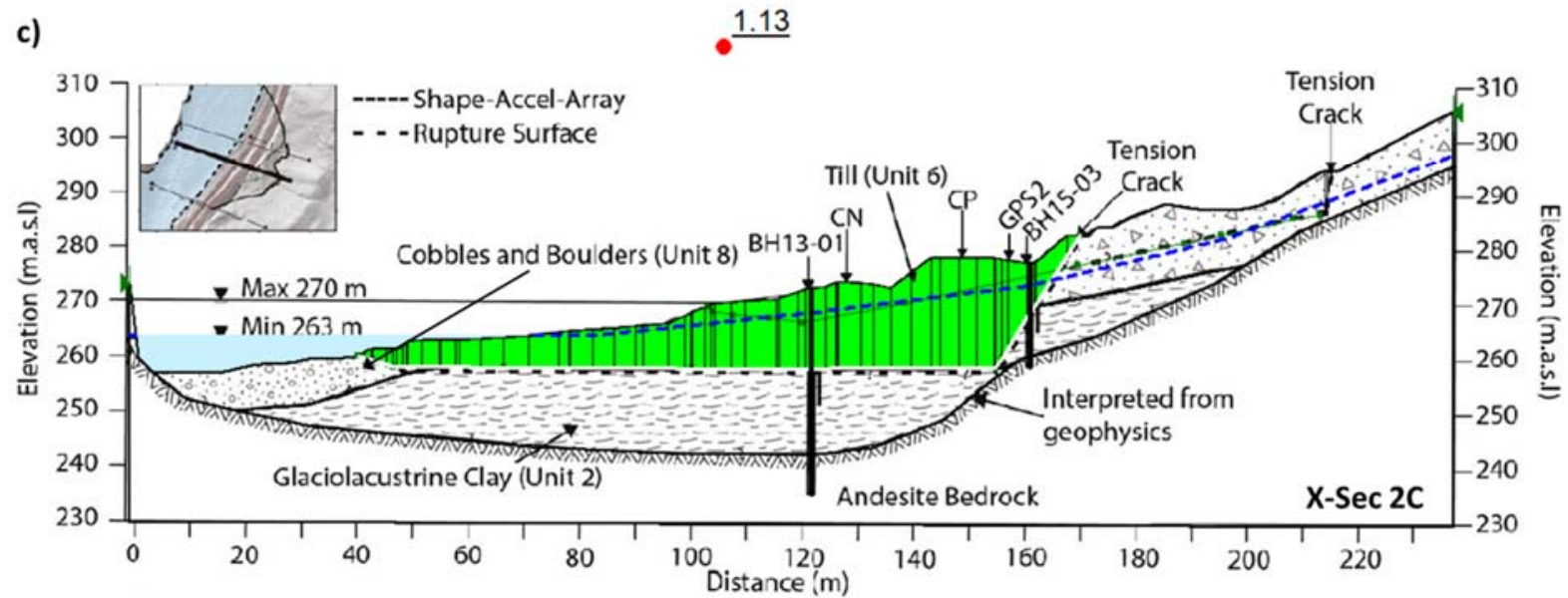

Fig. 14 Initial conditions and mesh for Ripley Landslide cross section $2 \mathrm{C}$ : a Slope stability domain showing two fully specified slip surfaces b Hydraulic boundary conditions c Starting point for FOS considering the hydrostatic contribution of suction in the unsaturated zone (overlay after Schafer 2016)

subsurface pore pressures during the resulting infiltration. River elevation was assumed to be constant (although measurements indicated a decrease of $15 \mathrm{~cm}$ ). Based on the previous analysis, a $7 \mathrm{~m}$ increase in river elevation would increase the FOS up to $19 \%$. Therefore, a $15 \mathrm{~cm}$ change has minimal impact on the overall FOS. Based on melt of a $0.3 \mathrm{~m}$ snowpack from the field measured air temperature, the overall FOS was reduced up to $10 \%$ based on the changing contribution of matric suction in the head scarp region (Fig. 15b).
There was no large precipitation event that coincided with snowmelt during the early months of 2020. Therefore, precipitation was modelled separately using the same initial FOS to determine its impact on stability. A $25 \mathrm{~mm}$ precipitation event occurred in early February 2020 (Fig. 15a) that caused the overall FOS to decrease (Fig. 15c) over a 15-day period. Daily fluctuations in the FOS are related to the calculation of the evaporative flux in the commercial software package. River elevation was also assumed to be constant for this 
analysis (measurements indicated a $6 \mathrm{~cm}$ drop over this period). Large spikes in precipitation impacted the contribution of matric suction to the interslice shear forces and were shown to cause up to $10 \%$ loss in the FOS (Fig. 15C).

a)

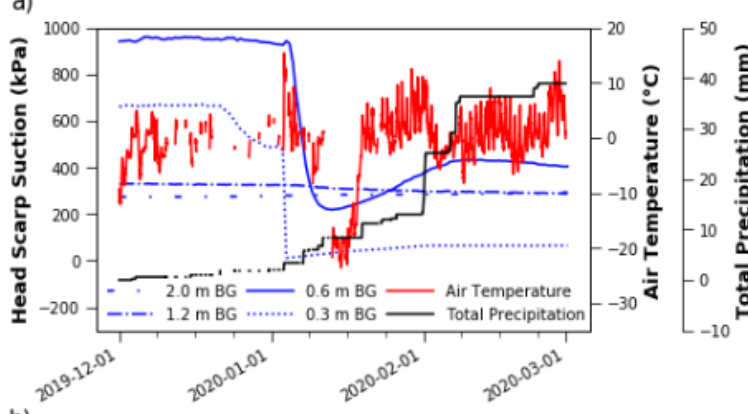

b)

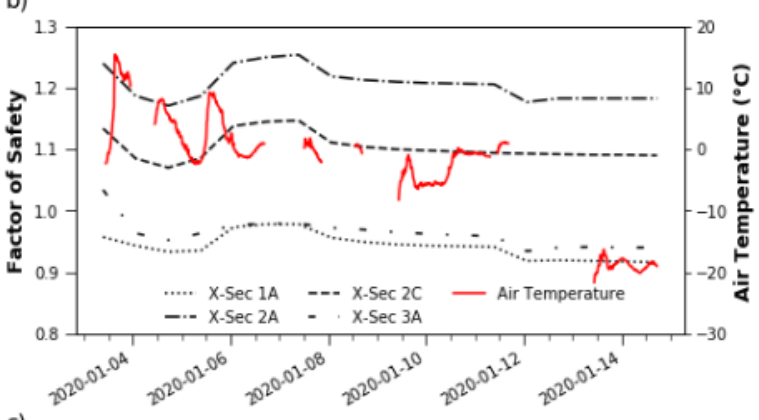

c)

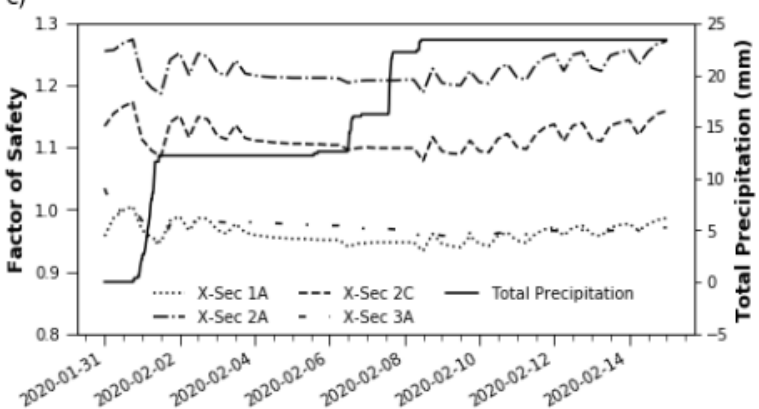

Fig. 15 Major input parameters compared to the relative drop in FOS: a Comparison of field measured head scarp suction against air temperature and total precipitation for Dec 2019 Mar 2020 b Drop in FOS due to $0.3 \mathrm{~m}$ snowpack melt (related to temperature) between Jan 3- Jan 15, 2020 c Drop in FOS due to precipitation between Jan 31 - Feb 15, 2020

Seasonal changes in river elevation are shown to have an overruling impact on the landslide stability (twice the change in FOS compared to typical snowmelt and precipitation events). However, when the river elevation is low, snowmelt and precipitation have the opportunity to lower the FOS even further, provided that the evaporative flux remains low. If long-term trends in soil moisture deficit dictate a wetter year, deeper pore pressures can be greater, and the synchronization of snowmelt with heavy precipitation events during this period of low river elevation would supplement the infiltration flux causing detrimental impacts on the landslide stability. At this time, the seepage analysis has not been calibrated with the two long-term matric suction boreholes. Future work will characterize water content across the ERT transects, providing better validation.

\section{Conclusions}

Methods of measuring, visualizing, and quantifying the impacts of changing water content in the vadose zone have been explored for the slow-moving, retrogressive translational Ripley Landslide in the Thompson River valley south of Ashcroft, British Columbia, Canada. Visualization and analysis tools for soil water content via electrical resistivity tomography and stable isotopes provide tools that verify the source and extent of infiltration. Further work is required to relate changes in electrical resistivity from the ERT to changes in soil water content. Matric suction sensors are valuable tools that provide field validation and will help to calibrate the water content estimated by the ERT. Long-term measurement of atmospheric parameters demonstrates multiyear trends leading to wetter subsurface conditions. Higher water content in the vadose zone reduced matric suction which contributes to increased landslide displacement rates. By combining the techniques used in this study, a better stability characterization of the Ripley Landslide was achieved. Future advancements in technology (from ERT to unsaturated lab testing methods) and resolution of weather data will inevitably change the relative importance of each method used in this study. In the meantime, a combination of each method's best traits provides the optimal investigative technique.

Stability calculations often only consider a snapshot of the site conditions and ignore the impact of water content in the vadose zone. However, near surface changes in water content due to infiltration, both in the long-term and the short-term, have been shown to influence stability and should not be considered negligible. Pore pressures generated in a transient seepage analysis fed into slope stability analysis that verified the potential influence of snowmelt and precipitation events on the overall stability of the Ripley Landslide. 2-D slope stability analysis conducted as part of this study reveals up to $10 \%$ reductions in FOS due to snowmelt or precipitation when the river elevation is at a minimum. Synchronization of cyclic fluctuations related to wet years (in terms of soil moisture deficit), absolute minimum river elevation, snowmelt, and precipitation events demonstrate landslide susceptibility to increased displacement rates at certain times of the year stretching over several years. By monitoring these factors, railway and other transportation infrastructure authorities can properly allocate funding and resources to prepare for potentially costly maintenance seasons.

\section{Acknowledgments}

Access to the Ripley Landslide for the research program was graciously provided to the authors by $\mathrm{CP}$ and $\mathrm{CN}$. Installation and monitoring of these instruments would not be possible without their ongoing support. Productive collaboration and data sharing with the 
Geological Survey of Canada and the British Geological Survey have been greatly appreciated as we work towards the common goal of protecting railway infrastructure. The authors would like to thank Transport Canada (TC), the (Canadian) Railway Ground Hazard Research Program (RGHRP), the Canadian Rail Research Laboratory (CaRRL), and Clifton Engineering Group for continued financial support and resources. These entities are supported by the Natural Sciences and Engineering Research Council of Canada (NSERC), CP, and CN. Holmes, Wilkinson, Chambers, and Meldrum publish with permission of the Executive Director of the BGS (UKRI).

\section{References}

Allen RG (1996) Assessing integrity of weather data for reference evapotranspiration estimate. Journal of Irrigation and Drainage Engineering 122(2):97-106

Allen RG, Pereira LS, Raes D, Smith M (1998) Crop evapotranspiration - guidelines for computing crop water requirements - FAO irrigation and drainage paper 56. Food and Agriculture Organization, Rome, Italy

Allen RG, Trezza R, Tasumi M (2006) Analytical integrated function for daily solar radiation on slopes. Agricultural and Forest Meteorology 139:55-73

American Society of Civil Engineers (2005) The ASCE standardized reference evapotranspiration equation. ASCE-EWRI Task Committee Report

Bishop AW (1959) The principle of effective stress. Teknisk Ukeblad 106(39):859-863

Bishop NF (2008) Geotechnics and hydrology of landslides in Thompson River Valley, near Ashcroft, British Columbia. MSc thesis, University of Waterloo, Waterloo, Canada

Blight GE (2003) The vadose zone soil-water balance and transpiration rates of vegetation. Géotechnique 53(1):55-64

Bobrowsky P, Huntley D, Neelands P, MacLeod R, Mariampillai D, Hendry MT, Macciotta $R$, Reeves $H$, Chambers J (2017) Ripley Landslide - Canada's premier landslide field laboratory. In: Proceedings Volume of the Geological Society of America Annual Meeting, Seattle, USA. $1 \mathrm{p}$

Brooks RH, Corey AT (1964) Hydraulic properties of porous medium. Colorado State University (Fort Collins), hydrology paper no. 3, March 1964

Bunce CM (2008) Risk estimation for trains exposed to landslides. PhD thesis, University of Alberta, Edmonton, Canada

Campbell GS (1988) Soil water potential measurement: an overview. Irrigation Science 9(4):265-273

Christiansen EA, Sauer EK (1984) Landslide styles in the Saskatchewan River plain: a geological appraisal. In: Proceedings of $37^{\text {th }}$ Canadian Geotechnical Conference, Toronto, Canada. pp 35-48

Clague JJ, Evans SG (2003) Geological framework of large historic landslides in Thompson River Valley, British Columbia. Environmental and Engineering Geoscience 9(3):201-212
Clark I, Fritz P (1997) Environmental isotopes in hydrogeology. CRC Press/Lewis Publishers, Boca Raton, USA

Craig H (1961) Isotopic variations in meteoric waters. Science 133:1702-1703

Environment Canada (2020) Historical climate data. Available from: climate.weather.gc.ca (accessed May 2020)

Eshraghian A, Martin CD, Cruden DM (2007) Complex earth slides in the Thompson River Valley, Ashcroft, British Columbia. Environmental and Engineering Geoscience 13(2):161-181

Eshraghian A, Martin CD, Morgenstern NR (2008) Movement triggers and mechanisms of two earth slides in the Thompson River Valley, Ashcroft, British Columbia, Canada. Canadian Geotechnical Journal 45(9):1189-1209

Fish Protection Act (1997) Province of British Columbia Ministry of Environment, Land and Parks. Bill 25, $2^{\text {nd }}$ Session, $36^{\text {th }}$ Parliament. Victoria, Canada

Fredlund DG, Morgenstern NR, Widger RA (1978) The shear strength of unsaturated soils. Canadian Geotechnical Journal 15(3):313-321

Fredlund DG, Rahardjo H (1993) Soil mechanics for unsaturated soils. John Wiley \& Sons, New York, USA

Fredlund DG, Xing A (1994) Equations for the soil-water characteristic curve. Canadian Geotechnical Journal 31(4):521-532

Fredlund DG, Xing A, Huang S (1994) Predicting the permeability function for unsaturated soils using the soilwater characteristic curve. Canadian Geotechnical Journal 31(4):533-546

Fredlund DG, Rahardjo H, Fredlund MD (2012) Unsaturated soil mechanics in engineering practice. John Wiley \& Sons, Hoboken, USA

Geoslope International Ltd. (2019) GeoStudio 2019 R2 Version 10.1. Available from: geoslope.com

Guan Y (1996) The measurement of soil suction. PhD thesis, University of Saskatchewan, Saskatoon, Canada

Gunn D, Chambers J, Uhlemann S, Wilkinson P, Meldrum P, Dijkstra T, Haslam E, Kirkham M, Wragg J, Holyoake S, Hughes P, Hen-Jones R, Glendinning S (2015) Moisture monitoring in clay embankments using electrical resistivity tomography. Construction Building Materials 92:82-94

Hage KD, Gray J, Linton JC (1975) Isotopes in precipitation in northwestern North America. Monthly Weather Review 103:958-966

Hargreaves GH, Samani ZA (1985) Reference crop evapotranspiration from temperature. Applied Engineering in Agriculture 1(2):96-99

Haug MD, Sauer EK, Fredlund DG (1977) Retrogressive slope failure at Beaver Creek, south of Saskatoon, Saskatchewan, Canada. Canadian Geotechnical Journal 14(3):288-301

Hendry MT, Martin CD, Choi E, Edwards T, Chadwick I (2013) Safe train operations over a moving landslide. In: Proceedings of the $10^{\text {th }}$ World Conference on Railway Research, Sydney, Australia

Hendry MT, Macciotta R, Martin CD, Reich B (2015a) Effect of Thompson River elevation on velocity and instability of 
Ripley Slide. Canadian Geotechnical Journal 52(3):257267

Hendry MJ, Schmeling E, Wassenaar LI, Barbour SL, Pratt D (2015b) Determining the stable isotope composition of pore water from saturated and unsaturated zone core: improvements to the direct vapour equilibration laser spectrometry method. Hydrology and Earth System Sciences 19:4427-4440

Hendry MT, Smith LA, Hendry MJ (2018) Analysis of the measured pore pressure response to atmospheric pressure changes to evaluate small strain moduli: Methodology and case studies. Canadian Geotechnical Journal 55(9):1248-1256

Holmes J, Chambers J, Donohue S, Huntley D, Bobrowsky P, Meldrum P, Uhlemann S, Wilkinson P, Swift R (2018) The use of near surface geophysical methods for assessing the condition of transport infrastructure. Civil Engineering Research in Ireland 2018 (CERI2018), Dublin, $6 \mathrm{p}$

Holmes J, Chambers J, Meldrum P, Wilkinson P, Boyd J, Williamson P, Huntley D, Sattler K, Elwood D, Sivakumar V, Reeves H, Donohue S (2020) Four-dimensional electrical resistivity tomography for continuous, nearreal-time monitoring of a landslide affecting transport infrastructure in British Columbia, Canada. Near Surface Geophysics 18: 337-351

Huntley D, Bobrowsky P, Hendry MT, Macciotta R, Best M (2019a) Multi-technique geophysical investigation of a very slow-moving landslide near Ashcroft, British Columbia, Canada. Journal of Environmental Engineering Geophysics 24(1):87-110

Huntley D, Bobrowsky P, Hendry MT, Macciotta R, Elwood D, Sattler K, Best M, Chambers J, Meldrum P (2019b) Application of multi-dimensional electrical resistivity tomography datasets to investigate a very slow-moving landslide near Ashcroft, British Columbia, Canada. Landslides 16(5):1033-1042

Huntley D, Bobrowsky P, Sattler K, Elwood D, Holmes J, Chambers J, Meldrum P, Wilkinson P, Hendry MT, Macciotta R (2020) Hydrogeological and geophysical properties of the very slow-moving Ripley Landslide, Thompson River valley, British Columbia. Canadian Journal of Earth Sciences, in press

Hutchinson JN (1995) Keynote paper: Landslide hazard assessment. In: Proceedings of $6^{\text {th }}$ International Symposium on Landslides, Christchurch, New Zealand. 3:1805-1841

Jarvis PG (1976) The interpretation of the variations in leaf water potential and stomatal conductance found in canopies in the field. Philosophical Transactions of the Royal Society of London 273:593-610

Journault J, Macciotta R, Hendry MT, Charbonneau F, Huntley D, Bobrowsky P (2017) Measuring the activity of the Thompson River Valley landslides, south of Ashcroft, BC, Canada, using satellite InSAR. Landslides 15(4):621636

Klassen RW (1972) Wisconsin events and the Assiniboine and Qu'Appelle Valleys of Manitoba and Saskatchewan. Canadian Journal of Earth Sciences 9(5):544-560
Leong E, Rahardjo H (1997) Permeability functions for unsaturated soils. Journal of Geotechnical and Geoenvironmental Engineering 123(12):1118-1126

Leroueil S (1999) Natural slopes and cuts: movement and failure mechanisms. Géotechnique 51(3):197-243

Macciotta R, Hendry MT, Martin CD, Elwood D, Lan $H$, Huntley D, Bobrowsky P, Sladen W, Bunce C, Choi E, Edwards T (2014) Monitoring of the Ripley Landslide in the Thompson River Valley, BC. In: Proceedings and Abstracts Volume Geohazards 6 Symposium, Kingston, Canada. $8 \mathrm{p}$

Macciotta R, Hendry MT, Martin CD (2016) Developing an early warning system for a very slow landslide based on displacement monitoring. Natural Hazards 81(2):887-907

Martin RL, Williams DR, Balanko LA, Morgenstern NR (1984) The Grierson Hill slide, Edmonton, Alberta. In: Proceedings of the $37^{\text {th }}$ Canadian Geotechnical Conference: Canadian case histories - landslides, Toronto, Canada. pp 125-133

Meter Group (2019) Teros 21 manual. URL: http://publications.metergroup.com/Manuals/20428_T EROS21_Manual_Web.pdf [Last accessed: Jan 15, 2020]

Mollard JD (1986) Early regional photointerpretation and geological studies of landslide terrain along the South Saskatchewan and Qu'Appelle River Valleys. Canadian Geotechnical Journal 23(1):79-83

Monteith JL (1965) Evaporation and environment. Symposia of the Society for Experimental Biology 19:205-234

Mualem Y (1976) A new model for predicting the hydraulic conductivity of unsaturated porous media. Water Resources Research 12(3):513-522

Pennell DG (1969) Residual strength analysis of five landslides. PhD thesis, University of Alberta, Edmonton, Canada

Rahardjo H, Leong EC (2006) Suction measurements. In: Proceedings of $4^{\text {th }}$ International Conference on Unsaturated Soils, Carefree, USA. Unsaturated Soils. Geotechnical Special Publication 147. Miller GA, Zapata CE, Houston SL, Fredlund DG (eds). ASCE, 1: 81-104

Ridley AM, Wray WK (1996) Suction measurement: a review of current theory and practice. In: Proceedings Volume 3 of $1^{\text {st }}$ International Conference on Unsaturated Soils, Paris, France. pp 1293-1322

Ridley A, McGinnity B, Vaughan P (2004) Role of pore water pressures in embankment stability. In: Proceedings of the Institution of Civil Engineers 157(4):193-198

Rozanski K, Araguas-Araguas L, Gonfiantini R (1993) Isotopic patterns in modern global precipitation. Geophysical Monograph 78. American Geophysical Union, Washington DC, USA. pp 1-36

Ryder JM, Fulton RJ, Clague JJ (1991) The Cordilleran ice sheet and the glacial geomorphology of southern and central British Columbia. Géographie physique et Quaternaire 45(3):365-377

Sassa K (2019) The Kyoto Landslide Commitment 2020: First Signatories. Landslides 16, 2053-2057

Sattler K, Elwood D, Hendry MT, Macciotta R, Huntley D, Bobrowsky P, Meldrum P (2018) Real-time monitoring of soil water content and suction within a slow moving landslide. In: Proceedings of $71^{\text {st }}$ Canadian Geotechnical Conference, Edmonton, Canada. $8 \mathrm{p}$ 
Sattler K, Elwood D, Hendry MT, Huntley D (2019) Additional tools for the study of variable water content effects on a slow-moving landslide. In: Proceedings of $72^{\text {nd }}$ Canadian Geotechnical Conference, St. John's, Canada. $8 \mathrm{p}$

Schafer MB (2016) Kinematics and controlling mechanisms of the slow-moving Ripley landslide. MSc thesis, University of Alberta, Edmonton, Canada

Siemens G (2018) Thirty-ninth Canadian geotechnical colloquium: unsaturated soil mechanics - bridging the gap between research and practice. Canadian Geotechnical Journal 55(7):909-927

Smethurst J, Clarke D, Powrie W (2012) Factors controlling the seasonal variation in soil water content and pore water pressures within a lightly vegetated clay slope. Géotechnique 62(5):429-446

Stanton RB (1898) The great land-slides on the Canadian Pacific Railway in British Columbia. In: Proceedings of the Institution of Civil Engineers, Session 1897-1898, Part II, Section 1, pp 1-46

Stewart JB (1988) Modelling surface conductance of pine forest. Agricultural and Forest Meteorology 43(1):19-35

Tarantino A, Ridley AM, Toll DG (2008) Field measurement of suction, water content, and water permeability. Geotechnical and Geological Engineering 26(6):751-782

van Genuchten MT (1980) A closed-form equation for predicting the hydraulic conductivity of unsaturated soils. Soil Science Society of America Journal 44(5):892898

Wassenaar LI, Hendry MJ, Chostner VL, Lis GP (2008) High resolution pore water $\delta^{2} \mathrm{H}$ and $\delta^{18} \mathrm{O}$ measurements by $\mathrm{H}_{2} \mathrm{O}_{\text {(liquid) }}-\mathrm{H}_{2} \mathrm{O}_{\text {(vapour) }}$ equilibration laser spectroscopy. Environmental Science and Technology 42(24):92629267

Yoshida RT, Krahn J (1984) Movement and stability analysis of the Beaver Creek landslide. In: Proceedings of $37^{\text {th }}$ Canadian Geotechnical Conference: Canadian case histories - landslides, Toronto, Canada. pp 223-231 